6 Alter C. Clinical diagnosis of the acute stroke syndrome. $Q J$ Med 1983;208:515-23

7 Kannel WB. In: Ross Russell RW ed. Cerebral arterial dsease. Edinburgh: Churchill Livingsione, 1983

8 Hypertension Detection and Follow-up Program Cooperative Group. JAMA 1979;242:409

\section{Infectious diseases in a Nicaraguan refugee camp in Costa Rica}

Theresa Diaz MD MPH

Columbia University College of Physicians and Surgeons, New York

R Achi MQC

Instituto de Investigaciones en Sahud (INISA),

Universidad de Costa Rica, San Jose, Costa Rica

TROPICAL DOCTOR, 1989, 19, 14-17

\section{SUMMARY}

Some Nicaraguans living in Costa Rica are in refugee camps. The types and rates of infectious diseases in the Pueblo Nuevo refugee camp were measured by examining medical records for 1985 and performing stool and blood testing. The incidence of infections was 320 episodes per 1000 persons per year. Respiratory infections represented $63 \%$ of all illnesses and pulmonary tuberculosis was high. Malaria was not found in blood samples and no childhood illnesses preventable by immunizations were recorded in the records. Intestinal parasites were found in $56 \%$ of the persons examined, considerably higher than the $15^{\circ} \%$ prevalence noted in surveys of Costa Rica as a whole. Trichuris Irichiura was found in $40 \%$ of the positive stool samples. The deficient hygienic conditions and overcrowding in the camp are responsibie for the high rates of infections and the continued presence of infections many of which probably were acquired in Nicaragua. Improvement of hygienic conditions can be accomplished by involving the refugees in education, cleaning and identifying problem areas. Adequate sanitation and improved water supply, and reducing overcrowding are aiso recommended.
9 Helgeland. A. Am J Med 1980;69:725

10 Harrison MJG. Hypertension and stroke. Br J Hosp Med 1984:215-8

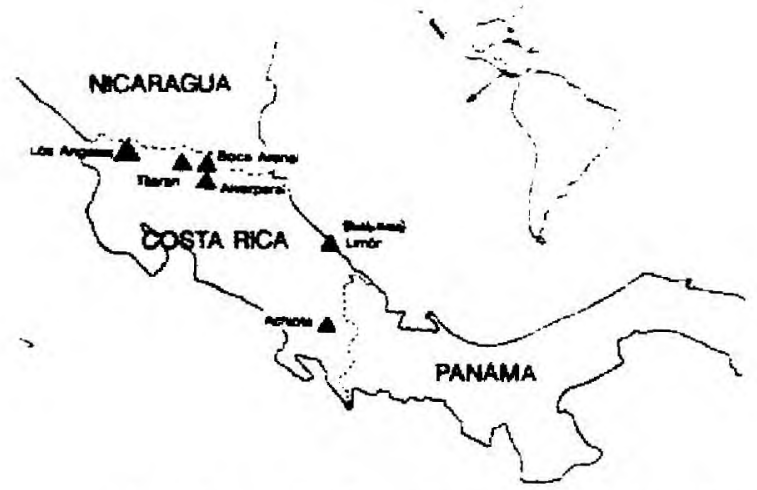

Figure 1. Map of Nicaragua and Costa Rica showing locations of refugee camps. (From Refugee Magazine, 20, August 1985)

\section{INTRODUCTION}

Costa Rica always had a considerable influx of Nicaraguans, predominantly poor. Since late 1984 the flow of refugees has been exacerbated with the intervention of the war. As of June 1985, there were 3000 new arrivals in refugee camps and a total of 9200 Nicaraguans living in different parts of Costa Rica'. There are 6 refugee camps in Costa $R_{i}$ it al: assisted by the United Nations High Commissione: for Refugees (UNHCR) (Figure i). Tilaran and Pueblo Nuevo in the North and East of Costa Rica respectively, are the oldest camps, and man! of their inhabitants have lived there for 2 years of more.

Each camp has more than 1000 persons. While Costa Rica has been praised for the higher standard of its camps, as compared to other countries, refugees live in overcrowded conditions, lack adequate sanitation and safe water, and experience high rates of infectious diseases ${ }^{2}$. This is indicated by a recent study in Tilaran ${ }^{2}$ which showed that $67 \%$ of children less than 7 years old had evidence of 
parasites, while in Costa Rica as a whole the rate is less than $15 \% \%^{3}$. The estimated rate for Nicaragua during that same time period was much more*

This study was conducted in January 1986, at Pueblo Nuevo camp 3 kilometers from the Port of Limon. The purpose of this study was to estimate rates of selected infectious diseases.

\section{BACKGROUND}

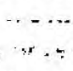

The camp, which opened in May 1983, had 1160 persons in June $1985^{5}$. The population consisted of Nicaraguans, $45 \%$ of whom are of African descent (from the West Indies), $40 \%$ Miskito, 14\% Mestizo and 1\% Ramas. By January 1986, the camp records showed 125 families with 650 persons and 100 single men not associated with families (a total of 750 persons). The people lived in either cement or wooden barracks, with 20-40 families per barrack and as many as 5 people living in an approximately $2 \times 4 \mathrm{~m}$ space. Cardboard walls separate the families. Most latrines and showers are located outside and as many as 10-26 people may share one latrine and shower ${ }^{5}$. The latrines are often soiled. Running water is from the Port of Limon; several sinks with running tapwater are located outside each barrack and one main tap is located in the centre of the camp. Often the water pressure is too weak to reach the taps. Food from one distribution centre located in the camp, is cooked on electric burners within the barracks. The people appear to have enough clothes, but often are barefoot. Refuse collection is twice a week by the Port of Limon. The camp is fumigated four times a year.

There is a health post in the camp staffed by one part-time medical practitioner and one full-time volunteer nurse (a refugee). The physician works 5 days a week in the camp for 3-4 hours each day, examining approximately 5-15 patients a day. The Health Post functions as a clinic for curative services. Prevention include immunizations and malaria case-finding for all new refugees ${ }^{5}$. Gynecological exams are not performed regularly. Stool examinations for parasites are not usually done. Suspected cases of intestinai parasitism were treated with oral mebeiciazole.

The administration of the camp, in the hands of 'Soccorro International", a religious organization, was transierred $10^{~}$ Centro de Analisis Sociopolitico fúa Ruugincss" (CASPRE). This new norreligious organization is supported by UNHCR.

\section{METHODS}

Impressions of the camp conditions were recorded, based on 6 days of observations in January 1986. All homes and barracks were briefly visited the first day of the investigation. Subseguently the living quarters of each participant in the stool servey, rwas, visited by the principal investigator Dr Diaz. Informal oral intervicws were conducted by this investigator during the daytime. The participants were asked severol questions inchuding; how many people occupied each living quarter, how was food obtained and prepared, where did each member of the household wash themselves and their clothes and where did each participant evacuale? The 1985 camp physician's report and all health records kept by the doctor for the year 1985 , were reviewed; only one physician worked in the camp during 1985. Annual incidences (number of new cases per 1000 persons per year) of selected infectious diseases were estimated by using the midyear population of 1160 persons.

The administration at the camp had a list of the 125 families residing in the camp. The average family size was 5 people. For this study all families in the camp were numbered and 25 families $(20 \%$ of the families) were picked at random for blood and stool testing. All 25 families agreed to participate in the study but approximately $15 \%$ of the people, mostly adult males, failed to attend. Stool samples were collected from 117 persons, $85 \%$ of the sample. Participants were instructed to collect a morming stool in a plastic container which was supplied. Blood samples were drawn from 87 people, $70 \%$ of the sample; 20 people refused.

Faeces were rapidly smeared onto glass slides, fixed in methanol for $5 \mathrm{~min}$ and stained with Giemsa for $30 \mathrm{~min}$. Faeces were suspended in polyvinyl alcohol Schaudinn (PVA) fixative. PVA preserved stools were directly examined in normal saline and Lugol's iodine. At least 50 fields were examined by the director of the microbiology laboratory at INISA. No stool concentratior. techniques were used.

The 36 blood samples in persons over 15 years of age, collected for VORL lestunn, were sent to the Ministry of Heaith. Eighty-seven malaria thin smear slides were fixed for 5 minutes in methanol, stained with Giemsa for 30 min and examines under an oi' immersion lens $(x+092)$. 


\section{RESULTS}

\section{Medical record review}

Based on the medical records, rates of infectious disease were calculated. The most common infections were respiratory, an estimated incidence rate of 200 respiratory episodes per 1000 persons per year (Table 1). Lower respiratory infections (LRI) were most common. Most (68\%) of upper respiratory infections (URI) occarred in children less than 10 years of age (Table 2). Pulmonary tuberculosis, diagnosed by acid fast staining, occurred in 4 cases per 1000 persons per year.

The second commonest group of infectious diseases included skin and mucosal infections, with an incidence rate of 70 episodes per 1000 persons per year (Table 1), half of which were pyodermitis (cellulitis, infectious impetigo and erysipelas) and $27 \%$ were cutaneous leishmaniasis.

Gastrointestinal (GI) infections inchuded anorexia, abdominal pain or diarthoea diagnosed clinically as gastroenteritis or intestinal parasites (without examination of stools). The incidence of GI infections was 55 per 1000 persons per year. Sixty per cent of $\mathrm{GI}$ infections were recorded as suspected parasitosis. Diarrhoea represented $38 \%$ of GI sympioms and was recorded mostly in children $(80 \%)$ less than 1 year of age.

The incidence rate of genitourinary infections was 28 episodes per 1000 persons per year (Table 1). Urinary tract infections (UTI) were the commonest (69\%) with $91 \%$ in women, all of whom were older than 15 years, $21.9 \%$ were urethritis, mostly in men over 15 years. It was not known whether the urethritis was gonococcal or non-gonococcal. Pelvic inflammatory disease was diagnosed in 2 women.

\section{Stool survey}

In 117 stools collected, $56 \%$ had one or more parasites. Trichuris trichiura was the commones: (40\% frequency), Giardia lamblia was second most common (23\% frequency) and hookworm the third (15\% frequency). One quarter of the stools collected had 2 or 3 parasites. Only 3 cases with Ascaris lumbricoides were observed, all in the same famil: Cryptosporiaium was found in two infant girls. Th: prevalence of intestinal parasites by age was simiici to the prevalence of the entire sample, with the excepion of the low rate $(25 \%)$ in children less than 1 year old.

IDRL and malaria testing

Two samples were positive with low titers ( $1: 1$ and $1: 2)$ and FTA-Abs tests confirmed syphilis in both.
Table 1. Infections disense, by system involved, Nicaraguans in Pueblo Noevo refugee camp, Costa Rica, 1985

\begin{tabular}{lrc}
\hline Group & $\begin{array}{c}\text { Number of } \\
\text { cases (\%) }\end{array}$ & $\begin{array}{c}\text { Incideace per } \\
\text { I000 persons }\end{array}$ \\
\hline $\begin{array}{l}\text { Respiratory } \\
\text { Skin and mucosal }\end{array}$ & $233(62.8)$ & 200 \\
$\begin{array}{l}\text { Gastroenteritis, intestinal } \\
\text { parasites, diarrhoea }\end{array}$ & $81(19.8)$ & 70 \\
$\begin{array}{l}\text { Urinary tract infection. } \\
\text { urethritis, pelvic inftammatory } \\
\text { disease, candidiasis }\end{array}$ & $32(7.8)$ & 55 \\
\begin{tabular}{l} 
Tota! \\
\hline
\end{tabular} & $410(100.0)$ & 28 \\
\hline
\end{tabular}

See Table 2.

'Includes cellulitss, infectious impetigo, erysipelas, conjunctivitis, varicella, leishmaniasis and scabies.

Table 2. Respiratory infections among Nicaraguan refugees, 1985

\begin{tabular}{lcc}
\hline Type & $\begin{array}{c}\text { Number of } \\
\text { cases. (\%) }\end{array}$ & $\begin{array}{c}\text { Incidence per } \\
\text { 1000 pensons }\end{array}$ \\
\hline $\begin{array}{l}\text { Lower respiratory } \\
\text { iliness }\end{array}$ & $100(42.9)$ & 86 \\
$\begin{array}{l}\text { Upper respira1ory } \\
\text { iliness }\end{array}$ & $83(36.5)$ & 73 \\
Oitus media & $18(7.7)$ & 16 \\
Otitis externa & $10(4.3)$ & 9 \\
Tonsilitis & $7(3.0)$ & 6 \\
Putmonary tuberculosist & $5(2.1)$ & 4 \\
Sinusitis & $5(2.1)$ & 4 \\
Pharyngitis & $3(1.3)$ & 2 \\
Total & $233(100.0)$ & 200 \\
\hline
\end{tabular}

Includes tracheobronchitis, bronchitis, trachitis, bronchiolitis. pneumonia, laryngeotracheobronchitis.

Diagnosis was made in sputum by acid fast staining.

Both individuals were women and one was pregnant. No cases of malaria were diagnosed.

\section{DISCUSSION}

There were several limitations to this study: Tre clinical retrospective analysis basec on the medical recorós represent a biased population. People who are iess ill and workers may be underrepresented while children and women may be cierrepresented. There was only one physician woinge at the cants and all the diagnoses wore based on his clinicai suspicions usualy without laboritory tests. The stool survey was a randomily selevied population based study but singte men 
were not included. It was felt they were more transitory and did not represent the stable refugee population. Also preserved stool samples were used and no concentrating techniques were applied $\mathbf{s 0}$ the actual rate of intestinal parasites may be higher.

Rates of intestinal parasites in the refugee comp and the high prevalence of Trichuris trichiurm were similar to those of Nicaraguans surveyed in Nicaragua and in the USA $4,6,7$, Costt Ricans have less than a $15 \%$ rate of parasitic infections 7,8 . Many cases of intestinal parasitism may have been originally acquired in Nicaragua but given the marginal hygienic conditions in this refugee camp, particularly related to disposal of faccal waste, the high prevalence of intestinal , parasitism is not surprising. Overerowding is likely to be responsible for the spread of many infectious diseases in the camp, particularly of tuberculosis and other respiratory infections9,10. The prevalence of lower respiratory infections suggest either a sicker community, selection bias or both. Lack of malaria identification seems to indicate good control of the disease, though it should be noted only thin smears were done. No reports of childhood diseases preventable by immunization were found reflecting either an adequate immunization programme or lack of transmission since these diseases are eradicated (polio) or rare in Costa Rica ${ }^{8}$.

Certain preventive measures must be taken to improve the health of the refugee community and curtail the spread of infections within the community. First the problem areas in the camp must be identified". For instance, in this camp, refugees were using the central faucet meant for drinking and cooking water alone, to wash themseives thus contaminating the water. Many people were barefoot, latrines were solled often with stool and urine on the floor, no water was available many hours each day and most refugees did nothing all day. Once the problems are identified many solutions are available. The refugees themselves should be involved in figuring out solutions as well as being responsible for their implementation. This could be done via self education, cleaning, identifying probiem areas and practising good hygiene. For example all new refugees should have stool examinations as well as refugees who have not had stool examinations previously. Refugees could assist with collection and encourage cooperation. Subsequently appropriate therapy could be given to those infected with parasites. A group of trained volunteers could provide education on hygiene. This should emphasize hand washing, wearing shoes, proper food hygiese and appropriate use of the latrines and water supply facilities. The camp administration should add a holding tank for water to ensure the presence of running water will be at all times. Though not done in this study, the water supply should be tested for parasites (i.e. giardia) and bacteria to locate the source of some infections and prevent their spread. Finally overcrowding should be reduced. Proper preventive measures will insure a healthier refugee community and maintain the health standards of the surrounding community.

\section{ACONOWLEDCAIENTS}

The author would like to thank $\mathrm{D}$. Leonurdo Matn who sugested this survey and contributed to its publication. Significamt serimance was provided by Drs Walter Munor, Wendy Sluser and Ramiro Barrantes. The manuscript was reviewed by Drs Louis Pizzarello, Jerry Paccione and Sten $H$ Vermund. The anthor would also like to thank the staff of INISA and CASPRE.

\section{REFERENCES}

1 Barton MS. Influx of refugees from Nicaragua to Costa Rica. Refugee Magazine 1985;20:20-27

2 Munoz W. Ramirez L. Alto Grado de Helmintiasis en Ninos Nicaraguenses Refugiados, Implicaciones para Costa Rica, 1985, unpublished

3 Mata $L$. The evolution of diarthoeal diseases and malnutrition in Costa Rica. Assignment Children 1983;61-62:196-224

4 Organizacion Panamericans de la Salud. Las Condiciones de Salud en las Americas 1977-J980. 1982

5 Mars F. The camp's physician report to UNCHR. June 1985. unpubiished

6 Sarfarty M, Rosenberg Z, Siegel J, Levin RM. Intestinal parasites in immigrant children from Central America. West J Med 1983;139:329-31

7 Ministerio de Salud Publica de Costa Kiza, Memoria 1984 , unpublished

8 Mohs E. Infectious diseases and bealth in Costa Rica: the development of a new paradigm. Pediatr Infect Dis 1982;1:212-6

9 Bull A. Hize KL. Acute respiratory infections: a review. Bull HHO 1978;56:481

10 Mohs $E$. Infecciones respiratorias agudas en Costa Rica 1965-1964: preveiancia, gravedad y letalidad. Bol Sanit Fanar. 1983:94:535-43

11 Dick B. Disease: of refugees-causes, effects and conmol. Trans R Soc Troo Hyg 1984:78:734-41 